Research Report No. 19/2008

\title{
Reconceptualizing Law and Politics in the Transnational Constitutional and Legal Pluralist Approaches
}

\author{
Ruth Buchanan \\ Osgoode Hall Law School of York University, rbuchanan@osgoode.yorku.ca
}

Follow this and additional works at: http://digitalcommons.osgoode.yorku.ca/clpe

\section{Recommended Citation}

Buchanan, Ruth, "Reconceptualizing Law and Politics in the Transnational Constitutional and Legal Pluralist Approaches" (2008). Comparative Research in Law \& Political Economy. Research Paper No. 19/2008.

http://digitalcommons.osgoode.yorku.ca/clpe/193 


\section{Comparative Research in Law \& Political Economy}

\section{Ruth Buchanan}

Reconceptualizing Law and Politics in the Transnational Constitutional and Legal Pluralist Approaches

EDTTORS: Peer Zumbansen (Osgoode Hall Law School, Toronto, Director, Comparative Research in Law and Political Economy, York University), J ohn W. Cioffi (University of California at Riverside), Lindsay Krauss (Osgoode Hall Law School, Toronto, Production Editor) 

CLPE Research Paper 19/2008

Vol. 04 No. 04 (2008)

\title{
Ruth Buchanan
}

\section{REConceptualizing LAW AND Politics in the Transnational Constitutional and Legal Pluralist APPROACHES}

\begin{abstract}
Despite the apparent fluidity that characterizes this historical moment as well as this moment in legal scholarship, this paper argues that there is also an enduring rigidity in the persistence of a modernist conception of law. In the way that the important questions raised for legal scholars in the current moment are identified as questions for legal theory, they are also already 'framed' in terms of a particular approach to the relationship between legality and legitimacy. This is revealed in debates over post-national constitutionalism which, even as they purport to transcend the nation-state, fail to escape some form of reinscription of the relation between law and a centralized sovereign authority. The author suggests that an alternative, more capacious approach to re-imagining law in the transnational might be found in a turn to legal pluralism, understood as a metaphor or style of thinking about law.
\end{abstract}

Keywords: Legal Pluralism, Postcolonial Legal Theory, Transnational Constitutionalism, WTO Constitutionalism

JEL classification: K10, K33

Author Contact:

Ruth Buchanan

Osgoode Hall Law School, York University

4700 Keele St. Toronto ON M3J 1P3

Email: rbuchanan@osgoode.yorku.ca 


\title{
Reconceptualizing LaW and Politics in the TransNational CONSTITUTIONAL AND LEgal PluRalist APPROACHES
}

\author{
Ruth Buchanan*
}

\section{I.}

In the world as seen through the lens of globalization, speeded up, networked, and restlessly materialist, revisiting 'foundational' questions of legal theory might first appear to be a hopelessly marginal and archaic exercise. Yet, these questions have become more, not less, relevant and pressing in the current context. In our world, as we have come to understand it, images, goods, technology finance, and people are linked in a vast network of trans-border exchange relations, a global market, which (we are told) threatens to destabilize and supercede the sovereign authority of nation-states.

This threat (perceived or real) to the nation-state is experienced as profoundly destabilizing, as the nation-state is the paradigmatic form in which law and politics have been imagined in modernity. That this is the case, despite (or perhaps because of) the fact that the form can be traced to a particular 'conception of the state-society relation, born within the parochial history of Western Europe [being] made universal' is perhaps an indication of how little the structure of the global system has changed since colonial times. (Chatterjee, 1993:238) The ostensible challenge to the nation-state posed by globalization has compelled public and scholarly debates in the west to revisit the longstanding (and perhaps irresolvable) questions of the foundations of legal authority. Contemporary efforts to re-imagine sovereignty 'beyond the nation-state' have opened a Pandora's box of questions regarding the very nature of law, the sources of law's legitimacy, and the relationship between legal and political authority.

\footnotetext{
* Ruth Buchanan is an Associate Professor of Law at Osgoode Hall Law School. She wishes to thank Peter Fitzpatrick for his generous and supportive editorial advice.
} 
What is less clear, however, is whether these reconsiderations will reflexively incorporate the insights of postcolonial scholars regarding the parochial origins of these ostensibly 'constitutive' discourses.

Herein lies the danger of current developments. To the extent that the phenomenon of globalization is reframed as a 'problem' of legal theory, I would argue, it becomes a problem whose 'solution' is already determined by the existent parameters of a particular discourse (of legal theory). (Gunther, 2003) One can see this most tellingly in the context of debates over 'constitutionalism' in the transnational context, where the often invisible 'touch of stateness' is acknowledged to be pervasive. (Shaw and Weiner, 2000) Indeed, many of the advocates for transnational constitutionalism are unapologetic about their adherence to an established 'vocabulary' or canon of conceptions that 'has undergone centuries of development and refinement within the context of the state'. (Walker, 2001:33) Admittedly, the post-national constitutionalism debate has germinated in the hothouse of the debates over constitutionalization of the European Union, where 'normative assumptions about the utility of constitutional thinking in the promotion of order, justice and civility in society and polities, even (perhaps particularly) beyond the bonds of the national state' may indeed be 'practically inescapable'. (Shaw, 2000:7) The debate has by no means remained confined to its original range, however. To bend the botanical analogy a bit more, one could suggest that the discourse of post-national constitutionalism has behaved more like an invasive species, proliferating wildly in locations where it did not originate, and where it faces no natural competitors.

One finds what I would identify as 'constitutional' approaches to questions of the relationship between 'legitimacy' and 'legality' beyond the nation-state in a broad swath of contemporary scholarship, from the modernist constitutional scholars referred to above to explicitly 'postmodern' treatments of global ordering. While scholars such as Hardt and Negri approach these questions in terms of a paradigmatic shift towards post-modern forms of social, legal and political ordering, the central preoccupations with law and politics, legality and legitimacy remain in place. Hardt and Negri set out to examine the 'constitution' of a new supranational world power they call Empire, framing their undertaking in terms of a 'global constitutionalism.'(2001:7) While Hardt and Negri critique the use of the 'domestic analogy' as a methodological 
tool for the analysis of supranational forms of ordering, they offer up their own conception of 'Empire' as a postmodern avatar of sovereignty, an emergent supranational juridical formation that corresponds to the 'totalizing' social and economic processes currently at work in the world. The (western) juridical problematic remains in place, albeit elevated to a new level.(Buchanan and Pahuja, 2004)

So, despite the apparent fluidity that characterizes this historical moment as well as this moment in legal scholarship, there is also an enduring rigidity, the persistence of certain kinds of constraints on our capacity to imagine legal forms. These constraints infect a broad range of seemingly disparate discussions, such that even those who herald this as a moment of (postmodern) transition are unwittingly caught up in the reproduction of the 'modern' form of law. It seems as if there truly is 'no way out of the (universal) code of legality'.(Gunther, 2003:16) This is the dilemma with which I (immodestly) propose to grapple in this article.

In what follows, I argue that although constitutional approaches, broadly conceived, purport to help us cope with the challenge to law presented by globalization, they do so by implicitly reinforcing a limited and limiting approach to transnational legality. Against this backdrop, the paper will present legal pluralism as an alternative approach by which one might examine shifts in the practices of regulation in a globalizing world without prejudging the question of legal form. I articulate my approach to 'legal pluralism' by distinguishing it from 'constitutional' or political pluralism. The former finds within the current moment an opportunity to radically reconceive of the production of transnational legalities outside or beyond the hierarchies and exclusions that have marked both the modern nation-state and the history of the interstate system, while the latter is constrained by a continued dependence on the institutionalized forms of law and nation. Thus, while constitutional pluralism is an approach the aim of which is to accommodate difference, it fails to foster plurality.

In contrast, then, with what I have (broadly) identified as 'constitutional' approaches, including those identified with 'constitutional pluralism', this article will propose that legal pluralism, as a metaphor, a frame, or a style of legal thinking, might provide a more productive avenue through which to approach the pressing issues of law's inclusivity and legitimacy in the transnational realm. This remarkable moment, in which legal theory is not 
'boring' but rather an intensely engaging and salient 'activity that participates in the life of its object' (Davies, 2002:3) presents an opportunity for legal scholars to participate in the emergence of new forms of transnational legality. The extent to which we are capable of reimagining the 'form' of law will make a significant difference to the fate of various emergent legalities; which will be nurtured and which suppressed.

\section{Post-National Constitutionalism}

Many have argued persuasively that in current times, it has become necessary to re-imagine both politics and law in a post-national frame. The quest for a 'post-national' constitutionalism has emerged in response to the perceived 'deficits' of governance at the transnational level: of democracy, legitimacy, accountability. It is a response that seeks to draw on the deep well of signification that constitutional discourse carries in the west. As Neil Walker observes, "the normatively continuous idea of constitutionalism is linked in a powerful and resilient chain of signification to a whole series of core governance values- democracy, accountability, equality, separation of powers, rule of law and fundamental rights." (Walker, 2002:344). For this reason, however, discussions of transnational governance seeking to draw on its rich legacy can also suffer from a degree of ambiguity. That is, the language of constitutionalism can be mobilized in different registers (institutional or theoretical), for dramatically opposing ends, by a range of differently situated actors who may nonetheless labor under the illusion that they are joining in a common debate. (Cass, 2001:41)

The debates over the turn to constitutionalism at the World Trade Organization are illustrative in this respect. Sparked by the institution's 'crisis of legitimacy' following the well-publicized failure of the Seattle Ministerial, which was attended both by internal dissension and noisy public protests, articles advocating constitutionalization of the WTO have proliferated in recent years. ${ }^{1}$ This growing attraction of constitutionalism

\footnotetext{
${ }^{1}$ The scholarly debate over WTO constitutionalization is expansive, and I don't purport
} to comprehensively survey it here. Some key interventions, however, include Cass, 2001, 
as an explanatory framework for current and anticipated developments in the international trading regime has been attributed to a myriad of factors. In the first instance, constitutional theory conventionally provides an account of the political foundations of legitimate legal authority, frequently called for in the WTO context. Secondly, the 'hands-tying' quality of constitutionalism appeals to advocates of a liberalized global trading order, such as Ernst Ulrich Petersmann, who see its benefits threatened by the potential capture of the domestic political process in member-states by various special interests.(Petersmann, 2000) But as well, constitutional discourse is increasingly understood as a framework within which competing normative claims, such as those of a growing chorus of non-state or civil society actors, are balanced and accommodated and hence, appeals to the constituency focused on the range of 'trade and...' concerns; environment, labor and development, for example.(Krajewski, 2001) In this way, constitutional discourse in the WTO context seems to offer all things to all people: it first grounds WTO law in political legitimacy, then sets it above the fray of politics, all the while promising a dispassionate arena for the fair resolution of fundamental normative disagreements.

This paper, however, seeks to move beyond the engaged institutional politics of transnational governance to consider the turn to constitutionalism in another 'key', that of legal theory. While jurisprudential inquiry is rarely an explicit part of contemporary discussions of 'post-national' governance, I would argue, it is almost always a significant part of what is going on. To this end, we might profitably pursue a further consideration of the 'constituent complicities' between sovereignty and law that lie beneath the constitutional narratives of law's foundation first within, and now, beyond the nation-state. (Fitzpatrick, 2003a:431)

In purporting to ground legal authority in a founding act of political will, constitutional theory appears to offer a type of 'practical' solution to the 'thorny issues of the non-foundational foundations of law.' (Teubner, 2004:16) A constitution is essentially an originary narrative that purports 
to unify and authorize both legal and political authority. ${ }^{2}$ As such, it cannot avoid the paradox, as Fitzpatrick so elegantly puts it, that "the origin has to 'be' before and after the point of origination." (Fitzpatrick, 2003b:48) A constitution, in order to found legal authority, does so by purporting to ground that authority in the political will of a 'people' understood to be capable of acting as a unified entity. But, the 'people' cannot come into existence as such until after the founding inaugurated by the constitution. Hence, the constitutional 'moment' must be understood as a sort of 'pious fiction'. (Hart, 1961:150) It necessarily presumes a pre-existing political order at the same time as it brings it into existence. "Constitutional law and discourse are no mere reflections of a prior political order, but are recursively implicated in the elaboration of that order.”(Walker, 2001:39) This 'political order' (simultaneously presumed and called into existence by the constitution) is also the source of sovereignty both for modern law and the modern nation.

It should be becoming evident by now that the assertion that in the constitution of sovereign nation-states we find the 'foundations' of modern law cannot be taken, as it frequently is in constitutional debates, as a claim regarding either the verisimilitude or immutability of that founding. Rather, it is the failure of those ostensible foundations that has become the subject of jurisprudential inquiry. In this vein, much of the recent work of Peter Fitzpatrick, among others, has revealed for us in careful and illuminating detail the impossibly commingled mythic foundations of law, nation and sovereignty in modernity. (Fitzpatrick, 2001 and forthcoming). And along these lines, I have argued elsewhere that law and nation are bound together by a mutual 'deferral' of foundational authority; "Law requires the nation-state to serve as the ultimate source of its authority, while at the same time, nation-states cannot come into being without law.” (Buchanan and Pahuja, forthcoming). It is true that law and nation are together fundamental to constitutional discourse, but not in the ways that constitutional scholars often imagine.

In conventional accounts, the primary challenge of the project of finding or creating a 'ground' for law beyond the nation-state thus is often

\footnotetext{
${ }^{2}$ On law's originary narratives generally see the contributions to S. Pahuja and J.L. Beard, 2004. Also, Buchanan and Johnson, forthcoming.
} 
represented in terms of the need to escape the 'touch of stateness', the (misleading) analogy with municipal or state law. This is based on an old but enduring contrast drawn between law's posited existence in the municipal realm and its deficient and tenuous existence in the international. (Hart, 1961) If, as I have suggested, municipal law draws this perception of both autonomy and stability from its 'constituent complicity' with nation, international law need not be understood as suffering from any particular 'lack' in regard to the matter of foundation. That is, in both the national and transnational contexts, the self-justifying narrative of law's foundations, the process of the 'bootstrapping' of legal authority, unfolds (and fails) in essentially the same way. That is, the law must rely on some notion of a pre-existing 'community' from which it draws its authority. That community, however, whether it is 'national' or 'international,' can only be constituted as a 'whole' by the demarcation of it that law brings about in its originary (constitutional) moment. This is why we frequently hear invocations of an 'international community' (sometimes in the guise of global civil society) intended to provide a legitimating 'ground' for law beyond the state. (Buchanan and Pahuja, forthcoming). And the turn to post-national constitutionalism is an extension of the same logic. The problem is, of course, that what is being presumed by these invocations is precisely the thing that must be thereby called into being. In this way, constitutional discourse itself takes the place, or rather, makes up, the sought after 'grounds' of law in both the national and international realms.

Not all of the advocates for a 'constitutionalization without the state,' however, begin from the assumptions that law's autonomy and authority are definitively secured 'within' the state and that international law must be defined in contrast, through its lack. Rather, some scholars have started with an acknowledgement of the continuities between domestic and international law, and focused on the extent to which the world of transnational law and politics already displays many constitution-like qualities. ${ }^{3}$ Here, the self-constituting or 'reflexive' nature of constitutional

\footnotetext{
${ }^{3}$ Although my primary references in this section are to Neil Walker and Gunther Teubner, my aim here is to draw a more general outline or 'ideal type' of approach that would appear sympathetic to a range of scholars currently working on issues of transnational governance from a pluralist constitutional perspective from Jo Shaw to James Tully. Further, it goes without saying that Walker and Teubner represent very
} 
discourse is not only acknowledged, but emphasized. (Teubner, 2004:7) That is, the 'process of mutual constitution and containment' of law and politics is acknowledged as a necessary, indeed defining, feature of constitutionalism. (Walker, 2001:34) ${ }^{4}$ As Gunther Teubner puts it, “The point is continually to understand the paradoxical process in which any creating of law always already presupposes the rudimentary elements of its own constitution, and, at the same time, constitutes these only through their implementation.”(p.16) This paradoxical relation is what holds law and politics, necessarily, both together and apart, enabling and constraining each. ${ }^{5}$ The task remaining for legal scholars, then, with respect to post-national constitutionalism is to identify and catalogue the aspects of evolving transnational legal regimes in terms of various 'constitutional' indices, including the emergence of hierarchically ordered norms, processes for self-review or interpretive autonomy, mechanisms for democratic representation or 'voice' and notably, the existence of a self-reflective constitutional discourse.

But this pragmatic embrace of the paradoxical nature of law's foundations, an insight already central to much contemporary legal theorizing, does not yet answer the question: what is sought to be achieved by the turn to the language of constitutionalism? It is here that the project of post-national constitutionalism is revealed as a normative, and not merely descriptive, undertaking. Reframing public and scholarly debates in constitutional terms, for these scholars, contains the potential to transform the ongoing process of transnational juridification in such a way as to bring into being the conditions for legitimate constitutionalization that are currently

different theoretical traditions, but in juxtaposing them in this way, I aim to illustrate the rather broad appeal of the 'reflexive constitutionalist' approach.

${ }^{4}$ Walker puts it this way, "Politics-in the grounded sense of the affairs of a polity-could not be conceived of without a constitutive legal setting and framework. Yet, on the other hand, constitutional law always presupposed some prior political setting-in the double sense of requiring a pre-existing political context for its mobilization and sustenance and re-imagining that political context...in its narrative of origins. Walker, 2002: 340.

${ }^{5}$ In the language of systems theory, "long term structural linkages of sub-system specific structures and legal norms are set up....The important effect of structural linkage is that it restrains both - the legal process and the social process - in their possibilities of influence.” Teubner, 2004:20. 
lacking. As Walker puts it, “...in the final analysis the ideological dimension of constitutional politics...is not the enemy of a normative discourse of responsible self government but rather its necessary accompaniment, and indeed, a central part of its generative context. (Walker, 2001:53). For Teubner, it is to 'guarantee the chances of articulating so-called non-rational logics of action against the dominant social rationalization trend, by conquering areas of autonomy for social reflection in long-lasting conflicts, and institutionalizing them." (Teubner, 2004:13) Both Walker and Teubner, albeit from within quite different theoretical models, appear to be basing the argument for constitutionalism on a belief in the salutary effects of constitutional discourse itself. In the end, this approach rests on the hope that constitutionalism will "(open) up a richer and more productive normative debate.” (Walker, 2001, p. 54)

Of course, the desire to 'open up a richer debate' still begs the question of what is to be debated. That is, to return to the objection registered at the outset, to what extent do even reflexive constitutional approaches predetermine the parameters within which transnational legality must take shape? Two tendencies are of concern here. Firstly, there is the way in which a call for constitutionalism is responsive to the discourse of 'deficits' mentioned earlier. That is, constitutional discourse is posited as a supplement, something that will supply 'more' of whatever is currently 'lacking' in transnational legality; democracy, accountability, legitimacy, or even, self-reflexive constitutional discourse itself. Relatedly, the call for constitutionalism implies both a hierarchy and a trajectory of transnational legalities, in which some emerging legal forms are imagined as more complete (constitution-like) than others. This trajectory, which might be said to parallel to the developmental hierarchy of states in the Westphalian order, has the effect of privileging certain legal forms, such as judicial norm-generation, over others. (Cass, 2001). Further, constitutional debates tend to focus on highly formalized and juridified entities such as the EU and the WTO, while an entity such as the World Social Forum, devoted to broadening and democratizing the public debate over transnational norms, is virtually ignored.

How is it then, that what I am calling 'reflexive constitutionalism' can also be identified with a concern for fostering plurality, such that it is sometimes identified as 'constitutional pluralism'? (Walker, 2002) Along with the focus on constitutionalism's autogenic quality there is an 
emphasis in this approach on the capacity of the 'constitutional' form to remake itself in a number of different ways. That is, this view suggests that constitutionalism can be 'disaggregated' into its component parts or indices, which can then be re-assembled in a number of different ways. Even the notion of 'sovereignty' is disaggregated and pluralized within this conception.(Walker,346) This formal or institutional pluralism is accompanied by another sense of pluralism, a recognition of the need to accommodate, within these various constitutionalisms, a diverse political landscape. That is, it connects with an "aspirational constitutional discourse which seeks to reshape the traditional intra-state constitutional sphere of the relations between different groups... within the state in ways which go beyond those legal forms of identity politics... that can be comfortably accommodated within the existing constitutional framework and ethos.”(Walker, 2002:354). In other words, reflexive post-national constitutionalism seeks to be more radically accommodating of plurality than various models of 'multicultural' constitutionalism at the municipal level have achieved. The means under consideration for the political pluralization of constitutionalism are themselves abundant, and beyond the scope of this article to assay. It must be pointed out, however, that at a certain point, the requirements of 'inclusivity' seems to demand of constitutionalism an impossible 'reflexivity'.(Christodoulidis, 2003:408) That is, it is the function of a constitution to represent a collectivity as a sovereign political subject. This representation is also an act of creation, a calling into presence, as the sovereign subject of law cannot exist prior to the moment it is 'constituted'. The constitution of a political subject, then, is also a moment of closure, of containment, and hence, exclusion. It is difficult to imagine how transnational constitutionalism, however plural or inclusive it aspires to become, can avoid this necessary implication.

In this regard, there is a further approach to constitutionalism, articulated most clearly by James Tully, that must be considered. Tully's 'agonistic constitutionalism' takes the dual requirements of reflexivity and plurality to their logical endpoints, potentially stretching the constitutional frame beyond recognition. He locates irreducible disagreement, even and perhaps especially over the rules of recognition or the rules of the rules, at the heart of the constitutional arrangement, rejecting any notion of 'consensus' in favor of 'continuously conciliated order'. (Tully, 2002). While Tully's account deserves far more consideration than I can give it here, I use it to illustrate the point at which we encounter most starkly the 
limits of the institutionalized form of constitutional discourse in relation to the demands of plurality. Tully doesn't seek to minimize or contain the challenge presented by pluralism, but rather seeks to deepen his own and our understanding of the 'density of relations of exclusion and assimilation' currently at work in the world. (2002:226) Most significantly, I think, in contrast to the majority of the debate over 'postnational constitutionalism' that I have sought to engage in this essay, he explicitly relocates the site of scholarly engagement away from 'the formalized institutions of deliberation' to the 'practices of and for democratic freedom (that) irrupt in opposition to (exclusions) in a multiplicity of nodes and networks and around a multiplicity of issues.'(p. 226)

In many ways, Tully's approach seems more in sympathy with both the tenor and intent of my own turn to legal pluralism than with the general outline of post-national constitutionalism that I have articulated thus far. It might also be observed here that Tully's approach shares some affinities with that of Hardt and Negri in Empire. Hardt and Negri identify their project as about the formation of a new global constitution; "In constitutional terms, the processes of globalization are no longer merely a fact but also a source of juridical definitions that tends to project a single supranational figure of political power.”(2000:9) In contrast with modernist approaches, Hardt and Negri acknowledge that the constitutional framework of Empire is marked by a series of 'explosive aporias' at its center. These 'aporias' represent the total absence of consensus (even imagined, projected or hoped for) concerning fundamental juridical questions of legitimacy, justice, and political order. (2001:20) In this sense, Hardt and Negri raise the same question of the limits of constitutionalism that Tully does. Does it make sense to continue speaking of a constitutional framework when the central characteristic of the framework in question is a radical indeterminacy? While I welcome the acknowledgements of reflexivity and plurality found in these latter approaches, I wonder about the perceived need to continue operating within a discourse of constitutionalism, and what irruptive potential these contributions could have that might be thereby contained. 


\section{Transnational Legal PluRAlism}

Our understandings of legal order are an integral part of the complex world of language, myth and metaphor in which we live and seek to make meaning. (Cover, 1983) I have suggested some ways that the enduring constitutional myth, through which law and political community perennially founds itself, might inflect the meanings we make of transnational legal orders in certain ways. Without purporting to be advancing anything resembling a developed 'theory,' in this final section of the paper, I wish to modestly propose 'legal pluralism' as an alternative metaphor for thinking about transnational legality. It should be clear that my effort here needs to be clearly distinguished from the various theories of legal pluralism as debated by legal scholars, especially those in the fields of anthropology and sociology of law. ${ }^{6}$ Further, and in relation to a more recently popularized debate, I am not advancing legal pluralism as a theory that is particularly well adapted to, or even compelled by, an analysis of emerging 'global' legal phenomena. (Teubner, 1997; Snyder, 1999)

Rather, I merely seek to speculate about what implications a metaphoric shift in our capacity to imagine legal forms, from 'constituted' to 'pluralist', might have. Of course, in order to do this, I need to first articulate more carefully what might be envisioned by such a shift. As a 'metaphor of multiplicity', a legal pluralist approach suggests a number of points of departure from mainstream constitutional accounts of law. It departs from the view that law is necessarily formal and can be institutionally identified with state action. It does not identify law exclusively with posited rules, distinct and territorially defined. And finally, it does not rely on a dichotomous construction of law and society (or politics). (MacDonald, 1998:74) In the place of the clearly delineated and identifiable form of law situated within the bounds of constitutional theory, we find in legal pluralism a view of law (including transnational law) as emerging from a plethora of often competing normative frameworks. (MacDonald, 73)

\footnotetext{
${ }^{6}$ For a useful recent reconsideration of the literature on legal pluralism, see Melissaris, 2004.
} 
In contrast to the unifying image of the constitutional moment, the legal pluralist imaginary encompasses multiplicity, heterarchy, and diversity. Legal pluralism allows us to think about the possibility for transnational legality without a 'center' or normative hierarchy. That is, the relationship between emergent transnational regulatory regimes need not be reduced to a necessary relation of superior/inferior as judged by the extent to which they are more or less 'legal' or 'constitutional'. Rather, they can be understood in a variety of ways: overlapping, discrete, competing, interpenetrated, mutually constitutive. In this way, the public discussion about the emergence and evolution of transnational legal norms is opened up to include a much wider range of formal and informal, institutional and discursive mechanisms. (Perez, 2003; 2004)

One way in which debates within a legal pluralist frame might be more inclusive is in the way in which they envision the participation of global civil society. Within contemporary debates in international law, belief in an already existing 'international community' appears as a necessary fiction. (Buchanan and Pahuja, forthcoming) That is because in mainstream approaches, the legal/political subject (here, civil society) can only be constituted, or 'called forth' by being 'called into line.' (Christodoulidis, 2003:426) To put it another way, the 'international community' of international law is a container that has determinate contours. For civil society to be contained within it, it must be made to fit. Those parts of civil society that do not fit, the 'irruptive' bits, are simply lopped off. For the legal pluralist, in contrast, it is the civil society that shapes the legal/political container, as much as the reverse. So, the presence or absence of shared normative frameworks becomes the very subject of inquiry. While much work has been done to more fully integrate the reconsideration of questions of recognition and participation into constitutional approaches, the risk of dealing with these issues in constitutional terms is that they will become just another institutional design problem; another procedural detail to be worked out by the institutional engineers of the global legal order. Yet, in the legal pluralist frame, the answers to such questions are not pre-given. Institutional frameworks, the meaning of participation and the sources of legitimacy can and likely will be multiple, contestable, and evolving.

As may have already become clear, there are important distinctions between this formulation of legal pluralism and the debates over the 
importance of and the need to account for political pluralism, which usually take place within a constitutional frame.

"Legal pluralism actually rests on almost the opposite intellectual presuppositions to political (democratic) pluralism. Far from simply acknowledging ethnocultural pluralism as a social fact and designing political institutions dependent upon a concept of abstract citizenship to accommodate it within a monist legal political order, legal pluralism is a radically heterogeneous concept. The plurality is not just of citizens, it is a plurality of legal orders as well- each operative within the same social space and each one of which exists independently of the others." (MacDonald, 76)

The distinction between political pluralism and legal plurality is crucial. Political pluralisms, despite their ostensible embrace of political diversity, may actually function to contain, even undermine, the recognition of legal pluralism by an implicit reliance on both a unitary conception of law and a correspondingly clear distinction between the 'legal' and 'political' realms. This can usually be seen to happen in one of two ways. Oren Perez has described the first variant of this as the 'Westphalian' approach, in which politics are seen as confined to the national level, while the work of international institutions is imagined as primarily legal and technical in nature. (Perez, 2003) This approach is a relatively common argument advanced by those who seek to keep pluralist politics 'out' of the WTO, for example. (Howse, 2002) But even constitutionally pluralist approaches that seek to integrate the accommodation of political pluralism directly into transnational law and institutions frequently invoke a centrist, rather than pluralist, conception of law. An example is found in the approach adopted by de Burca and Walker, (2003) in their role as editors of a collection of essays on the topic of 'Law, Civil Society and Transnational Economic Governance”. In their account, although they acknowledge the multiple discourses of civil society in careful detail, law is represented as a ‘central steering mechanism': “One general and 
overarching question concerns the possibilities and limits of the role of law, in its institutional and discursive specificity, within the post national setting...does law, as a central steering mechanism, inevitably organize civil society in such a way as to reduce its autonomy?” (p. 389). The way the question is posed here, I would argue, prefigures its answer. If law is conceived as both centralized and autonomous, that is, an institutionalized realm of 'coordination' that is separate from politics, it is hard to imagine it as capable of facilitating the multiple and diverse politics currently being advanced in the international realm by contemporary global civil society actors.

In contrast, the metaphor of legal plurality facilitates a reflexive approach to the relationship between law and politics in the international realm. That is, law provides a fluid and evolving space and discourse within which competing normative claims are debated, engaged, negotiated and compromised. Law and politics are not imagined as discrete realms of activity, with law in the drivers seat, as it were. Rather, they are tied together in a mutual relation of 'constituent complicity'. From within this perspective, we can consider how new instantiations of transnational political practice, such as those exemplified by various transnational movements for global social justice over the past decade, might influence the form of transnational legal regimes, as well as the converse. Global civil society exists and operates from within relatively more 'disorganized' and 'organized' manifestations, yet a focus on its relation to more 'constitution-like' legal forms such as the World Trade Organization will tend to highlight the activities of the relatively more organized nongovernmental organizations, and those activities in particular that are specifically directed towards the 'constitution' of that institution. (Christodoulidis, 2003; Buchanan, 2003) The 'metaphor of multiplicity' suggests that law is not only or necessarily imagined in this way, as the necessary 'institutional' container of an unruly and disruptive 'politics' that is 'prior' to law but must be authorized by it. The form of law itself needs to also be understood in its more 'disorganized' form, as potentially plural, disruptive, subject to re-conceptualization and transformation. This is not to say that unitary, or constitutional, conceptions of law are somehow false, however. Rather, my intent has been to elaborate upon the metaphor of legal plurality in response to what I have perceived as a dominant tendency towards unified, constitutional representations of law. 
I do, however, believe that this moment in which the foundational questions of law, questions concerning the 'authority of authority', seem to once again be open to consideration, presents an opportunity. Allowing ourselves to re-imagine transnational legal institutions and the politics surrounding them with the metaphor of legal plurality, I argue, might allow us to perceive emerging forms of 'global' law, perhaps from unexpected places. The authors of these new forms of global law could well be those 'critical beings', those who, like refugees or illegal migrants, find themselves occupying the most inhospitable and interstitial spaces of the transnational order, and who are denied the protection of a settled or determinate law. (Fitzpatrick and Tuitt, 2004) Like these new 'global subjects', new forms of 'global law' could well emerge from a myriad of marginal, improbable or discredited sources.

Law holds out a promise to the world of both plurality and inclusivity, a dual promise that we must continue to seek to realize in the transnational realm, even as its failures are more poignantly clear than ever. As legal theorists, although we may not be able to change the world or its laws, we can choose the metaphors through which we represent them. Metaphor is one means by which we can continue to insist upon the necessity of opening up for questioning the extent to which current forms and frameworks of transnational law realize our aspirations for it. This opening to questioning is a 'permanent task', one that perennially refuses any determinate settlement of the question of the foundations of legal authority. ${ }^{7}$

\footnotetext{
7 The phrase 'permanent task' is James Tully's. Although I have raised questions about his adherence to a language and framework of constitutionalism, I concur with his elegant formulation of our social and legal order as a permanent work in progress; 'we are always in the position of beginning again the permanent task of testing the limits of our freedom by means of our freedom.” (2003:228).
} 


\section{REFERENCES}

Buchanan, Ruth and Pahuja, Sundhya (2004) "Legal Imperialism: Empire's Invisible Hand?” in Paul A. Passavant and Jodi Dean, eds., Empire's New Clothes: Reading Hardt and Negri (Routledge: NY and London.)

Buchanan, Ruth (2003) "Perpetual Peace or Perpetual Process: Global Civil Society and Cosmopolitan Legality at the World Trade Organisation” Leiden Journal of International Law 16 :673-699.

-and Rebecca Johnson, (2005) "The Unforgiven Sources of International Law: Nation-building, Violence and Gender in the Western" Doris Buss and Ambreena Manji, eds. International Law: Modern Feminist Perspectives (Hart: Oxford).

-and Sundhya Pahuja, (2004) "Law, Nation and (Imagined) International Communities” 8 Law Text Culture 137-166.

Cass, D Z, (2001) “The 'Constitutionalization' of International Trade Law: Judicial Norm Generation as the Engine of Constitutional Development in International Trade”, European Journal of International Law, 12(1), pp.39-75.

Chatterjee, Partha, (1993) The Nation and its Fragments: Colonial and Post Colonial Histories (Princeton University Press, Princeton, N.J.)

Christodoulidis, Emilios, (2003) "Constitutional Irresolution: Law and the Framing of Civil Society”, European Law Journal, 9(4) pp. 401-432.

Cover, Robert, (1983) ‘Nomos and Narrative’ 97 Harvard Law Review 4.

Davies, Margaret (2002) Asking the Law Question: The Dissolution of Legal Theory $2^{\text {nd }}$ Edition (Lawbook Co.: Sydney)

de Burca, Grainne and Walker, Neil (2003) "Law and Transnational Civil Society: Upsetting the Agenda?” 9:4 European Law Journal 387-400. 
Fitzpatrick, Peter, (2001) Modernism and the Grounds of Law (Cambridge University Press: Cambridge)

--(2003a) 'gods would be needed...' American Empire and the Rule of (International) Law 16:3 Leiden Journal of International Law 429-466.

--(2003b) 'Breaking the unity of the world: Savage Sources and feminine law’ Australian Feminist Law Journal, 19 pp. 47-60

--(2004) "We know what it is when you do not ask us': The Unchallengeable Nation” 8 Law, Text, Culture 263.

---and Tuitt, Patricia, (2004) “Introduction” in Peter Fitzpatrick and Patricia Tuitt (eds.) Critical Beings: Law, Nation and the Global Legal Subject Ashgate: Aldershot.

Gunther, Klaus, (2003) "Legal Pluralism and the Universal Code of Legality: Globalisation as a Problem of Legal Theory” unpublished manuscript, http://www.law.nyu.edu/clppt/program2003/readings/gunther.pdf (last visited September 27, 2004).

Hart, H.L.A., (1961) The Concept of Law (Clarendon Press).

Hardt, Michael and Negri, Antonio, (2001) Empire (Cambridge: Harvard University Press).

Howse, Robert, (2002). "From Politics to Technocracy - And Back Again: The Fate of the Multilateral Trading Regime.” American Journal of International Law 96: 94-117.

Howse, Robert, and Nicolaidis, Kalypso, (2003) "Enchancing WTO Legitimacy: Constitutionalization or Global Subsidiarity?” in Marco Verwej and Tim Josling (eds.) Deliberately Democratizing Multilateral Organizations, Governance: An International Journal of Policy, Administration and Institutions 16:73-94.

Krajewski, Martin (2001) “Democratic Legitimacy and Constitutional Perspectives of WTO Law” 35 Journal of World Trade 167-186. 
MacDonald, Roderick, (1998) "Metaphors of Multiplicity: Civil Society, Regimes and Legal Pluralism” 15 Arizona Journal of International and Comparative Law 69-91.

Melissaris, Emmanuel, (2004) "The More the Merrier? A New Take on Legal Pluralism” 13(1) Social and Legal Studies 57-79.

Pahuja, Sundhya and Beard, Jennifer, eds. (2004) Divining the Source: Law's Foundation and the Question of Authority (Griffith University Press).

Perez, Oren, (2004) Ecological Sensitivity and Global Legal Pluralism: Rethinking the Trade and Environment Conflict (Hart: Oxford).

-(2003) “Normative Creativity and Global Legal Pluralism: Reflections on the Democratic Critique of Transnational Law" Indiana Journal of Global Legal Studies 10:2, pp. 25-64.

Petersmann, Ernst-Ulrich (2000) “The WTO Constitution and Human Rights” Journal of International Economic Law 3:1.

Shaw, Jo, (2000) "Process and Constitutional Discourse in the European Union 27 Journal of Law and Society 4-37.

Shaw, J. and Weiner, A., (2000) "The Paradox of the European Polity" in M. Green Cowles and M. Smith (eds.) State of the European Union 5: Risks, Reform, Resistance and Revival (OUP: Oxford)

Snyder, Francis, (1999) “Governing Economic Globalization: Global Legal Pluralism and European Law” 5 European Law Journal 4:334-374.

Teubner, Gunther, (2004) "Societal Constitutionalism: Alternatives to State-Centered Constitutional Theory?” in Joerges, Sand and Teubner, eds. Transnational Governance and Constitutionalism (Hart: Oxford) 3-28.

-(1997) “Global Bukowina’: Legal Pluralism in World Society’, in Gunther Teubner ed., Global Law Without a State (Aldershot: Brookfield, USA) 3-28. 
Tully, James, (2002) “The Unfreedom of the Moderns in Comparison to Their Ideals of Constitutional Democracy” Modern Law Review 65:204228.

Walker, Neil, (2001) "The EU and the WTO: Constitutionalism in a New Key" in G. de Burca and J. Scott, eds. The EU and the WTO: Legal and Constitutional Issues” (Hart: Oxford).

-(2002) “The Idea of Constitutional Pluralism” 65:3 The Modern Law Review 317-359. 